\title{
Open access awareness and perceptions in an institutional landscape
}

Serrano-Vicente, R. Universidad de Navarra. Servicio de Bibliotecas. Campus Universitario, 31009 Pamplona, Spain. E-mail: rserranov@unav.es. Tel: +34 948425 600; fax: +34 948178269.

Melero, R. Instituto de Agroquímica y Tecnología de Alimentos-CSIC. Profesor Escardino 7, 46980 Paterna, Valencia, Spain. E-mail: rmelero@iata.csic.es. Tel: +34 963900 022; fax: +34 963636301.

Abadal, E. Universitat de Barcelona, Facultat de Biblioteconomia i Documentació. Melcior de Palau, 140, 08014 Barcelona, Spain. E-mails: abadal@ub.edu. Tel: +34 934035 773; fax: +34 934035772.

\section{Abstract}

INTRODUCTION. The aim of this study was to determine the awareness of open access among the academic staff of a research-oriented Spanish university, their use of the institutional repository and their satisfaction with its services.

METHODS. An anonymous survey of 37 questions was sent to all professors, researchers and doctoral students of the University of Navarra. Between 5 and 25 March 2015, a total of 1989 messages were sent by email with a link to the survey.

RESULTS. A total of 352 responses (17\%) were received. The responses showed statistically significant differences in opinions concerning open access journals and services created on top of the repository. Although there was general agreement on the need for open access, half the respondents adopted open access practices (which included the use of the institutional repository, personal and departmental pages and academic platforms such as Academia.edu and ResearchGate). This percentage increased with the older respondents, who were also senior members of staff with tenure and positions of authority at the university. The opinion on open access journals depended on the area of research and was related to the type of academic communication and career advancement in each discipline. Specifically, the opinions of researchers were similar within social sciences and humanities, within medicine and life sciences, and within the physical sciences. The repository services most valued were correction of bibliographic data among older researchers and document scanning among social sciences and humanities researchers. The interoperability of the repository with other systems (especially the current research information system) was also considered important.

Key words: Institutional repository, Open access journals, Open access, Services on top of repositories, Open access institutional policy 


\section{Introduction}

Since the birth of the open access movement, one of its main objectives has been to free scientific output, mainly generated with public funds, from the economic barriers and copyright restrictions that prevent it from being freely accessible online. Universities and research centres that support and encourage open access to scholarly outputs have created institutional repositories to facilitate the dissemination, access, reuse and preservation of the work arising from the scientific and academic activity of their staff. In addition to fulfilling the functions of access, dissemination and preservation, repositories provide support services derived from their content and aimed at the academic and research community, such as usage statistics and metrics, generation of curricula vitae, links to social networks, and search engines. Knowledge of the services most demanded by researchers will allow repository managers to develop the most useful ones and foster the use of their repositories (Lynch, 2003). Only in this way will institutional repositories become an important channel in the cycle of scientific communication.

Many universities have adopted their own institutional open access policies. However, this is not sufficient to create change in the habits of researchers. It is important to determine their awareness and degree of compliance, and to find ways of monitoring compliance. With these aims, several studies have investigated the attitudes and habits of agents involved in the generation and dissemination of knowledge with a view to analysing the advantages and difficulties arising from this paradigm shift towards open access by default.

Kim (2007) proposed an explanatory model of the factors that hinder or encourage the contribution of researchers to the institutional repository. The model classifies the motivations that influence researchers to participate in the institutional repository into four categories: costs, extrinsic and intrinsic benefits, contextual factors, and individual characteristics. The costs refer to obtaining copyright and the extra time and effort involved in archiving their publications in the repository. The extrinsic benefits that can be obtained are accessibility (a permanent URL of their document), visibility (wider dissemination and greater possibility of citation), confidence (social processes that ensure quality, based on the standards of a specific community: e.g. the peer review system), academic reward and professional recognition. The intrinsic benefit is altruism (a desire to share the benefit of their publications with others). The contextual factors are related to incentives for collaboration with the repository, the creation of a culture for change in the habits of researchers, and the quality of the repository. The same author (Kim, 2011) published the results of a survey conducted in 17 universities with repositories, including questions about self-archiving and awareness of the institutional repository, perceptions of self-archiving, and plans for self-archiving in the future. The results showed that only $40 \%$ knew of the institutional repository, that professional category influenced participation in the repository, and that tenured professors were more likely to participate in the repository than tenure-track professors, who were under pressure to obtain a post. According to this study, the two reasons that most influenced self-archiving were preservation of the work and concern about violation of the copyright of published works.

Xia (2007) conducted a survey in seven repositories of Australia, Sweden and the UK in four areas of research: chemistry, physics, economics and sociology (in physics and economics there is a prior culture of depositing in subject repositories), with the aim of investigating whether self-archiving was more likely in some subjects than in others. The results showed that experience in depositing documents in subject repositories did not lead to an increase in the number of these documents in institutional repositories. However, it was found that mediated deposit and the existence of an institutional mandate of the university concerned influenced the depositing of documents. No differences between researchers from different disciplines were found. 
The PEER (Publishing and the Ecology of European Research) project brought together the various actors in academic publication (editors, researchers, libraries, repositories and target users) to study the relationship between open access and scholarly communication. The study showed that, although there was a good general understanding and appreciation of the effectiveness of open access, there were clear differences between researchers from different disciplines in their understanding of depositing their publications in institutional repositories and their motivations for doing so (Creaser et al., 2010). Although two thirds of the respondents knew what open access was, their understanding of it differed according to the discipline. Researchers in medicine and life sciences associated open access with the gold road, whereas researchers in physics and mathematics and social sciences and humanities associated it more with the green road. Researchers in physics and mathematics preferred subject repositories, whereas researchers in social sciences and humanities preferred the institutional repository. Researchers of medicine and life sciences preferred publication in open access journals with a strong reputation that follow the "author pays" model, and they linked this factor to the building of their academic reputation. By areas, the most important reason for depositing works in social sciences and humanities was the increase in citations; in life sciences it was free access to all; in medicine it was peer review of articles; and in physics and mathematics it was rapid publication. In general, all the authors indicated that there was a conflict between institutional mandates for depositing research results in open access and the growing pressure to publish in journals with a high impact factor. The difficulties most mentioned were lack of knowledge of journal permissions and embargo periods for self-archiving. When asked about the future, although some thought that open access might jeopardize the current peer review system, the results suggested that the review of articles could be organized outside academic journals, perhaps using 2.0 tools. The second stage of the project analysed the behaviour of researchers when they disseminated their research results and the adoption of the green road of open access according to disciplines (who deposited, how, why, which versions, and the difficulties encountered). Among the results obtained, it is noteworthy that more than half the respondents deposited a version of their articles, either themselves or through mediation. The data were studied by disciplines, and some differences were found between the behaviour of researchers in physics and mathematics and that of researchers in medicine and life sciences: the former preferred depositing in subject repositories (a consolidated habit in Arxiv) and the latter in institutional repositories. Physicists and mathematicians tended to self-archive voluntarily, even in the institutional repositories. On the other hand, researchers in medicine and life sciences delegated the archiving to third parties when they were required to do so by the repository manager or the institution. As for which version was deposited, the final version was the most common among researchers in medicine and life sciences, while the rest (physics and mathematics, social sciences and humanities) used the pre-print or the accepted and corrected version of the manuscript (Spezi et al., 2013).

At the University of Wisconsin-Eau Claire (UWEC), a small public university focusing more on teaching than on research, a survey was conducted in 2011 to ascertain the degree of awareness of open access among professors, which potentially had a direct relation to the depositing of material in the repository. Of the respondents $(105,26 \%$ of the total), $30 \%$ were unable to give a basic definition of open access, and the rest had limited knowledge of it. The motivations that most led them to publish in a journal were career advancement, the impact factor of the journal, the importance of the journal in their discipline, and rapid publication (Kocken \& Wical, 2013).

In another study conducted at the University of Rosario in Argentina (Bongiovani, Guarnieri, Babini, \& Lopez, 2014) to obtain the views and practices of researchers regarding open access and their needs regarding the institutional repository, the results indicated that $80 \%$ of respondents agreed with open access, but only $13 \%$ used the institutional repository to disseminate their research because they were not aware of it. The main motivation for depositing publications in the repository was the use that could be made by their colleagues, students and the general public. The most valued services offered by the repository were advanced searching and statistics. 
In 2012, the Directorate-General for Research and Innovation of the European Union carried out an international survey on scientific information in the digital age (Commission \& Directorate-General for Research, 2012). The survey addressed four areas: Europe's role in the circulation of knowledge; access to scientific publications; access to research data; and the preservation of digital scientific information. Among its most important results, it is noteworthy that $90 \%$ of respondents believed that publicly funded research data should be in open access. More than half the respondents thought that the issue of preservation had not been sufficiently addressed.

In 2013 and 2014 Taylor \& Francis Publishing carried out surveys on open access and repositories among authors who had published in their journals (Frass, Cross, \& Gardner, 2014). The survey asked their opinion on open access and on the future of open access publication. It also asked about the licences they preferred for publishing in open access, the practices they followed in submitting articles for publication, repositories, mandates at the regional level, and desirable services under the open access umbrella. The results showed that the respondents thought that open access journals had a greater circulation and visibility, were published more quickly and had more readers. However, they did not think that they received more citations. The most frequent reasons for depositing were personal responsibility to place research in open access, requests by colleagues for published articles, the request of the institution, and placing in open access by the publisher. The most frequent reasons for not depositing were lack of knowledge of editorial policies, lack of time, and lack of knowledge of how to deposit documents in the repository.

In a survey in medical schools in Tanzania, a country with a lesser development of repositories, most respondents claimed to use open access journals to disseminate their articles. The barriers to open access found were low internet bandwidth, lack of knowledge of open access and lack of skills for depositing documents in the repository. It was also found that senior researchers were more likely to offer open access to their publications than junior researchers (Lwoga \& Questier, 2015). The Texas A\&M University has had an institutional open access policy since 2013, and despite its short existence, the degree of awareness of the policy and the institutional repository among professors and researchers is high (Yang and Li, 2015). However, the biggest difficulty found by its researchers was how to deposit documents, followed by concerns about copyright issues and the feeling that the contents of the repository were of lower quality.

A study was recently published on the knowledge and experience of researchers of German public universities regarding open access journals and self-archiving (Eger et al., 2015). The results show that the attitude of the researchers to open access depended on factors such as age, position, area of research, and the form of self-advancement in each discipline. It was found that researchers in biology and life sciences were more active in open access journals but more reluctant to deposit documents on online platforms. On the other hand, researchers of mathematics and statistics, physics and astronomy, and economics self-archived more and used open access journals very little. The authors considered that this could be because the impact factor of open access journals differs according to disciplines.

One must also take into account the academic platforms on which communication between authors is now carried out: Academia.edu, ResearchGate, etc. A very recent study analysed the effect on the number of citations of uploading the works on the Academia.edu platform versus not uploading them. With a sample of more than 30,000 articles, the authors concluded that a paper published in a journal with a medium impact factor receives $16 \%$ more citations after a year than an article not available online, 51\% more after three years and 69\% more after five years (Niyazov et al., 2016).

The University of Navarra, small and research-oriented size, is a private university created in 1952 with a high percentage of international students in master's degrees (44.6\%) and doctoral degrees (34.2\%). The courses in medicine are highly valued, and are complemented by practice in Clínica Universidad de Navarra. Communication studies are also important because Navarra was the first 
university to offer a university degree in journalism. The University of Navarra ranks seventh in Spain in research productivity, being only surpassed by the large public universities (Pérez, 2015). In 2008 the university created an institutional repository containing more than 31,000 documents. It also includes the journals published by the University's Publications Service (36 titles).

The aims of this study were to determine the degree of awareness of open access, the use of the institutional repository of the University of Navarra (DADUN) and the satisfaction with the services provided by the managers of the repository (Serrano-Vicente, Melero, \& Abadal, 2014). It also aimed to determine how far the repository is integrated in the academic communication of researchers, why they deposit their work in the repository, and what difficulties they encounter in doing so.

\section{Methodology}

Taking as a reference the three surveys mentioned in the introduction (Commission \& DirectorateGeneral for Research, 2012; Frass et al., 2014; Spezi et al., 2013), we drafted a questionnaire to determine the respondents' awareness of and participation in open access, their awareness of DADUN, how often they accessed DADUN, and how satisfied they were with it. The Google Forms tool was used to create the online survey for distribution via the internet. The survey was previously sent to a group of professors and researchers to obtain their opinions on the wording and response time. Most replied that the survey was clear and easy to answer, and some made suggestions that were applied before the survey was sent to other researchers.

Through a distribution list, a message with a link to the survey was sent to all professors and postgraduate students of the Pamplona and San Sebastian campuses of the University of Navarra. Of a total of 2087 messages, about 100 were returned as undeliverable, leaving a total of 1989 potential respondents. The survey was sent in four batches from 5 to 25 March 2015.

The questionnaire (see Appendix) was divided into four parts:

Part 1. Descriptive data: Faculty, Department, Discipline, Area of Work, Type of User and Age (Q1, Q2, Q3)

Part 2. Open Access: The opinion and attitude of respondents with regard to open access, their practices in sharing their publications in open access, and the platforms they used (Q4-Q9).

Part 3. Open access journals: Respondents were asked whether they had published in open access journals, and what they thought of these publications in comparison with the traditional form of access to and distribution of research work (Q10-Q15).

Part 4. Open access at the University of Navarra: We wished to know whether respondents were aware of the existence of the open access policy that has been in place at the University since June 2014. We also asked whether they knew and used DADUN, the reasons why, how they self-archived, and what they thought of the services it offers (Q16-Q37).

\subsection{Data analysis}

For the statistical analysis we used the SPSS statistical package, version 23. 
Frequencies and percentages of responses to all parts of the questionnaire were calculated. For questions Q10-Q15 and Q30-Q37 contingency tables were made and the chi-square $(p<0.05)$ was applied to analyse the dependence or association between groups taking into account age and discipline. A Spearman correlation test was applied to non-parametric variables to assess bivariate correlations between age groups and disciplines.

In questions Q10-Q15 and Q30-Q37 we discarded values of the type "Don't know" or "I don't use it" for statistical analysis but not for counting the total number of responses. In questions Q10-Q15 and Q20, Q30-Q37, for which the responses were graded (Totally agree, Partly agree, Agree, Strongly agree in Q10-Q15; Very often, Often, Regularly, Sometimes, Never or almost never in question Q20; and Not at all important, Unimportant, Important, Very important in Q30-Q37), the Kruskal-Wallis H test was applied by age and discipline. In cases in which the significance was less than $0.05(p<0.05)$ a pairwise Mann-Whitney $\mathrm{U}$ test was used to compare independent samples.

\section{Results and discussion}

Of the 1989 surveys sent, a total of 352 responses were received. For a population of this size and with a margin of error of $5 \%$, the minimum would be 333 , so the sample used is significant for the study population, with an error probability of $\alpha=0.05$.

\subsection{Descriptive data}

We reduced the number of categories because of the low presence of some groups, and respondents were grouped by age and discipline. The age and discipline groups were well balanced, with an approximate range of $30 \%$ to $40 \%$ each (Table 1). For the data of respondents by age and subject, the chi-square test did not allow the null hypothesis to be rejected, so there was no association between discipline and age group of individuals $(p=0.802)$.

Table1. Groups of respondents by age and working area.

\begin{tabular}{|l|r|r|r|}
\hline \multirow{2}{*}{ Working area } & \multicolumn{3}{|c|}{ Age } \\
\cline { 2 - 4 } & $\mathbf{2 5 - 3 5}$ & $\mathbf{3 5 - 4 5}$ & $\mathbf{4 5 - 6 0 +}$ \\
\hline Social sciences & $31.6 \%$ & $29.5 \%$ & $38.9 \%$ \\
\hline Humanities & $34.8 \%$ & $33.7 \%$ & $31.5 \%$ \\
\hline Health and Life sciences & $38.7 \%$ & $27.4 \%$ & $34.0 \%$ \\
\hline $\begin{array}{l}\text { Engineering, Physics, } \\
\text { Maths and Chemistry }\end{array}$ & $40.3 \%$ & $30.6 \%$ & $29.0 \%$ \\
\hline
\end{tabular}

\subsection{Open access}

This section summarizes the results of the responses to questions Q4-Q8 on awareness of the open access movement at the university. 


\subsubsection{Analysis by age}

The attitude towards open access was mostly positive. Regardless of age group, over $90 \%$ of respondents thought that publications should be available on the internet as soon as possible, that open access facilitates contact with other researchers, and that it can contribute to the visibility of their work. However, 52\% of the 25-30 age group stated that they had not placed their publications in open access in recent years, whereas $84 \%$ of the $45-60$ age group had done so.

At first sight it may seem surprising that younger respondents use open access less, because of their greater potential skills with new technologies and social networks. However, these results are consistent with most of those reviewed in the literature, which show that maturity and academic status are associated with greater participation in open access (Eger et al., 2015; Kim, 2011; Lwoga \& Questier, 2015). Only one of the articles studied, belonging to a university in Ghana, indicated that older researchers were less involved in the repository because they consider it to be of poorer quality (Oguz \& Assefa, 2014). Researchers normally see a conflict between the institutional open access mandate and pressure to publish in journals with a high impact factor. In the case of young researchers who are beginning their academic career, this problem is greater, and they therefore tend to place their works less in open access.

\subsubsection{Analysis by subject area}

The analysis by subject area also showed few differences (Figure 1). Though the chi-squared test revealed some association of medicine and life sciences with regard to whether open access encourages contact between colleagues, in real terms the percentages of "yes" and "no" answers were of the same order for all disciplines. A slightly higher proportion of researchers in social sciences and humanities thought that open access encourages contacts, possibly because the digitization of the university's own journals had allowed them to distribute their print-only publications through the institutional repository, and this had promoted their research in circles that they had not previously reached.

Figure 1. Responses about open access by working area of respondents. 


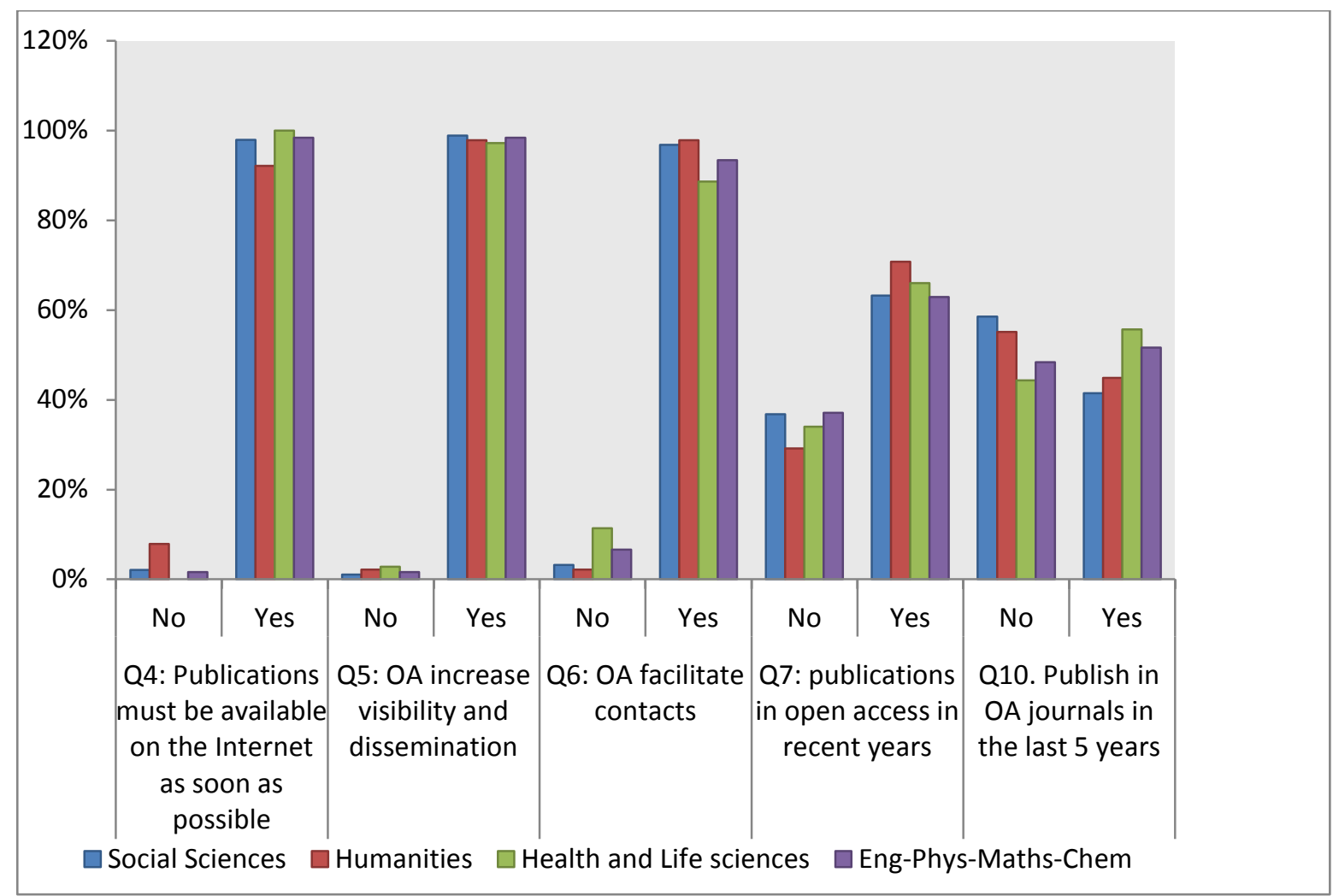

With regard to whether they had placed their publications in open access in recent years (Q7), the analysis by subject area showed no differences between the four groups: an average of $66 \%$ said that they had placed their publications in open access in the past five years. Of this $66 \%, 30 \%$ had placed their work in DADUN, $24 \%$ in open access journals, $17 \%$ in Academia.edu, $7 \%$ in ResearchGate , $4 \%$ in other dissemination media and $3 \%$ in subject repositories. By contrast, $15 \%$ of respondents said that they had not placed their work in open access. Therefore, the respondents considered open access to include open access journals, DADUN and other academic platforms (ResearchGate, Academia.edu, etc.), and other departmental and personal pages. These results are similar to those obtained in the survey conducted by Taylor \& Francis in 2013 and 2014. The respondents disagreed or strongly disagreed with the statement that publishing in open access was not beneficial to them (60\% and $70 \%$ in 2013 and 2014, respectively). However, 52\% had not deposited their last article in open access; those that had done so had used an institutional repository or a personal or department website ( $23 \%$ in both cases).

Studying these data by subject (Figure 2), we found that DADUN was the most equally represented in the four subject areas, with $20 \%-40 \%$. Medicine and life sciences published mainly in open access journals (47\%) and also showed the highest use of ResearchGate (14\%). Respondents in the physical sciences (engineering, physics, mathematics and chemistry) showed a preference for the institutional repository (44\%), followed by open access journals (24\%) and were the ones who most used subject repositories (13\%). Humanities and social sciences researchers showed a preference for the institutional repository ( $36 \%$ and $35 \%$, respectively). These results coincide with those obtained in the survey conducted for the PEER project (Creaser et al., 2010). It should be noted that researchers in physics and mathematics were among the first to participate in the institutional repository at this university, as they were accustomed to depositing their works in subject repositories and on the department website. The survey found that researchers in medicine and life sciences published in open access journals that charge publishing fees, and considered that this was good for their career. Researchers in humanities and social sciences discovered open access with the institutional repository, in which the university's journals had been scanned and published. Following this trend, 
they had deposited their articles in the institutional repository. In medicine and life sciences the open access journals are fewer and of lower quality.

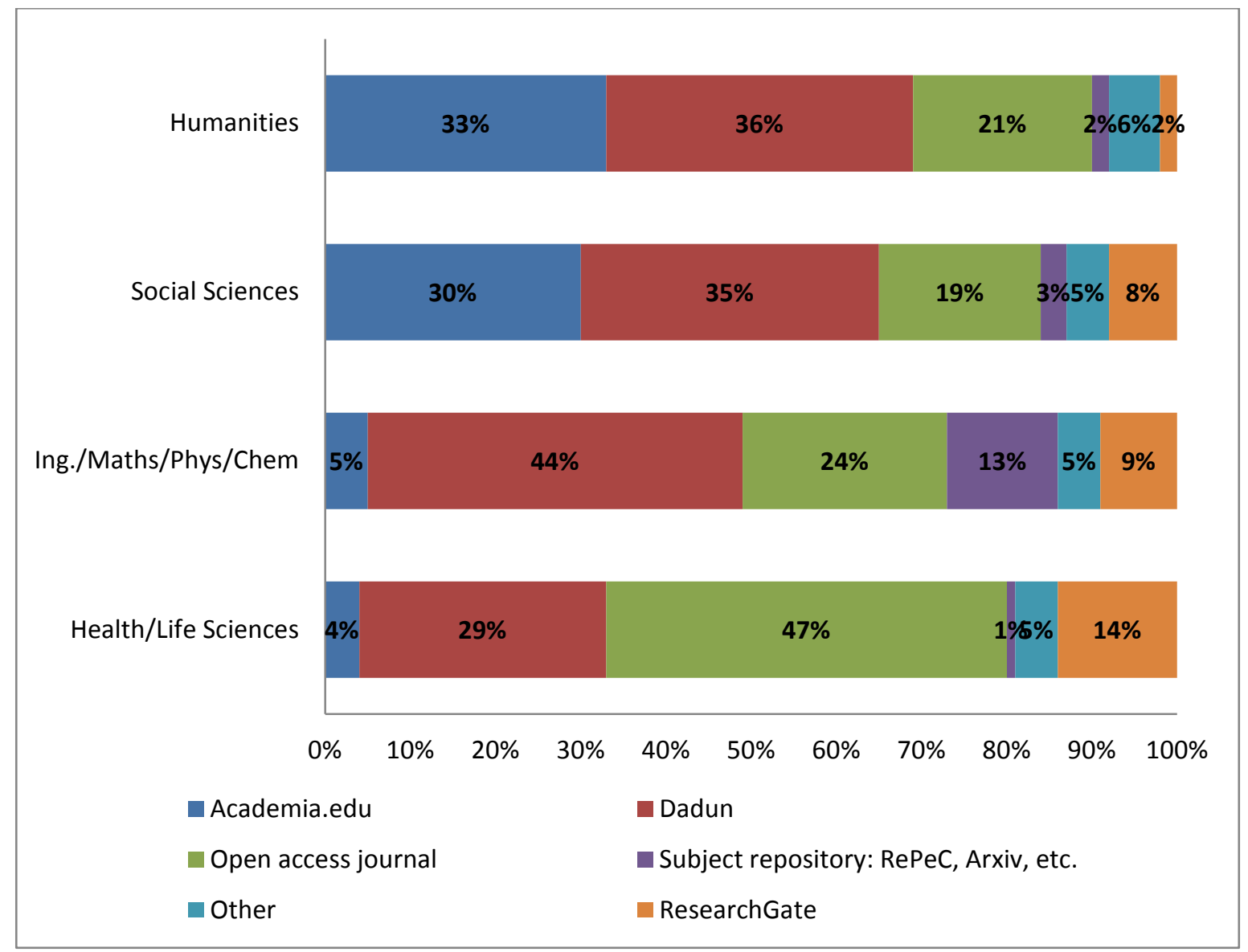

Figure 2. Publication in open access by working area of respondents

The results for the Academia.edu and ResearchGate platforms are interesting. Researchers in the social sciences and humanities were the ones who most used Academia.edu, almost in the same proportion as the institutional repository (presumably they used both). On the other hand, medicine and life sciences and physical sciences researchers used ResearchGate more. As seen above, publications uploaded on the internet have been found to obtain $16 \%$ more citations in the first year (Niyazov et al., 2016). The increase in citation when works are placed in open access was most valued by social sciences and humanities researchers. Life science researchers most valued free access to all, medical researchers most valued peer review, and physics and mathematics researchers most valued rapid dissemination (Creaser et al., 2010). It is therefore clear that each discipline uses the open access media that are best suited to its objectives.

Of the suggestions made by respondents, most compared DADUN with academic platforms. Although they thought it was desirable to deposit works in the repository, they used academic platforms more because it was easy to upload documents on them and they were sure that their colleagues would read their publications on them.

We asked where they found the journal copyright policy regarding permissions to disseminate their work in open access. The respondents most often found the policy on the website of the journal or publisher and, if they were unable to find it, they asked for permission to add their documents to the repository. Continuing in order of frequency, the researchers used the library services or 
international directories (Sherpa/Romeo or Dulcinea). Finally, $7 \%$ of the respondents claimed to have found the rights through other means, including the ResearchGate platform. This question is interesting because one of the greatest concerns of researchers in adding their work to repositories is their lack of knowledge of legal issues related to copyright (Creaser et al., 2010; Frass, Cross, \& Gardner, 2014; Kim, 2011; Yang \& Li, 2015). Many of the respondents have now changed from an attitude of concern to one of actively seeking editorial policies, which means that they have found a motivation for depositing their documents in the institutional repository.

\subsection{Open access journals}

The second part of the questionnaire focused on the respondents' knowledge and opinion of open access journals (Q10-Q15). They were asked to express their opinion on whether open access journals contributed more to the dissemination of work, were faster in publishing content than subscription journals, were read more than restricted access journals, and were more likely to be cited. Finally, the respondents were asked how open access journals compared to restricted access journals in terms of quality (Figure 3 ).

\subsubsection{Analysis by age}

No dependence was detected between the ages of the researchers and their responses according to the chi-squared test). The same was found by the Kruskal-Wallis test. A pairwise Mann-Whitney $U$ test revealed no differences between groups as the significance was always $p>0.05$. About $70 \%$ of respondents agreed or strongly agreed that open access journals offered faster publishing and wider dissemination. No clear trend was observed in factors affecting quality and use by researchers (higher readership, citation and quality), with a tie of about $50 \%$ between those who agreed and disagreed. However, these results varied according to the discipline of the respondents, as seen in the following section.

In the survey conducted by Taylor \& Francis in 2014, the results were similar to those obtained in this study, with the exception of citation: in our case many researchers (39\%) did not think that open access journals obtained more citations. 


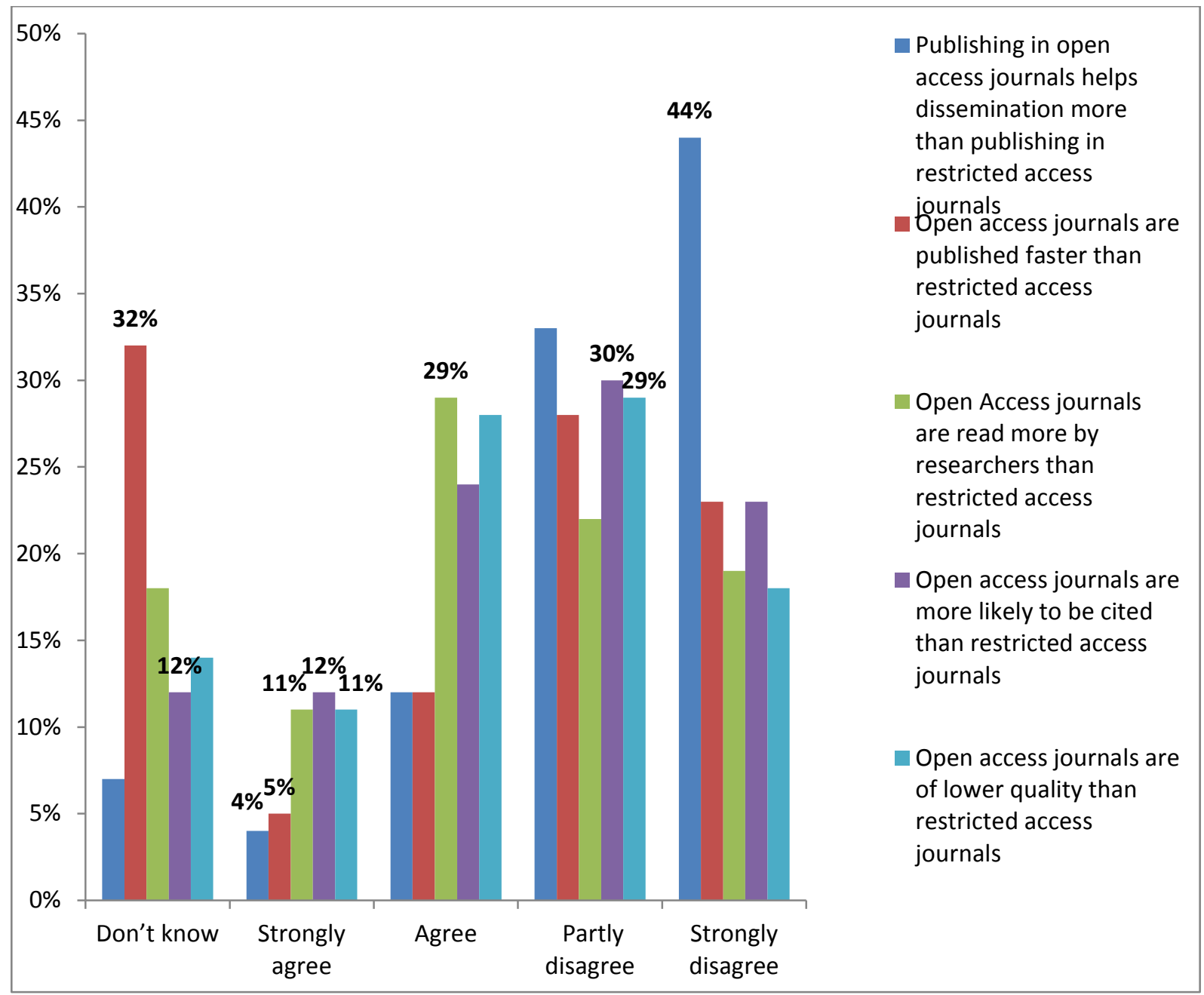

Figure 3. Opinion about Open Access Journals (Total)

\subsubsection{Analysis by subject area}

The analysis by subject area was significant. Researchers in medicine and life sciences were those who most thought that open access journals were published faster. Social sciences researchers were those who most thought that open access journals were read more, possibly because the cost of subscription to these journals is zero and the budget for social science journals in university libraries is smaller than that of medicine, life sciences and physical sciences

When the Kruskal-Wallis test was applied by disciplines, significant differences $(p<0.05)$ were found for the answers to Q13, Q14 and Q15. When the pairwise Mann-Whitney $U$ test was applied between disciplines (Table 2), no differences were detected between social sciences and humanities or between medicine and life sciences and physical sciences in the responses on open access journals, but the responses of social sciences and humanities differed from those of medicine and engineering.

According to the literature review, researchers from social sciences and humanities consider that they can obtain more citations if they publish in open access (Creaser et al., 2010). Researchers from life sciences consider that the most positive aspect is that research is freely accessible to all (Creaser et al., 2010; Eger et al., 2015); researchers in medicine consider that the most important aspect is 
peer review (Creaser et al., 2010) and the least important is rapid dissemination; and researchers in physics and mathematics consider that rapid dissemination is the most important aspect (Creaser et al., 2010; Eger et al., 2015). In our study, we found that respondents in the social sciences had similar views to those in humanities, and respondents in medicine and life sciences had similar views to those in physical sciences. Researchers in social sciences and humanities were those who most considered that open access journals allow them to obtain more citations, showing a significant difference from researchers in the physical sciences, who most disagreed with this statement. Researchers in medicine and life sciences considered that the most important aspects were that open access journals were peer-reviewed and available to all. Researchers in the physical sciences considered that open access journals achieved greater dissemination but they were the group who least published in open access journals.

Table 2. Mann-Whitney $U$ test to compare questions about open access journals by pairs of subject categories (empty cells means $\mathrm{p}>0.05$ )..

\begin{tabular}{|c|c|c|c|c|c|}
\hline & $\begin{array}{c}\text { OA } \\
\text { journals } \\
\text { +Dissemin } \\
\text { ation } \\
\text { (Q11) }\end{array}$ & $\begin{array}{c}\text { OA } \\
\text { journals_+Rapid } \\
\text { (Q12) }\end{array}$ & $\begin{array}{c}\text { OA } \\
\text { journals_+Read } \\
(\mathrm{Q} 13)\end{array}$ & $\begin{array}{c}\text { OA } \\
\text { journals_+Cited } \\
(\mathrm{Q} 14)\end{array}$ & $\begin{array}{c}\text { OA } \\
\text { journals+Quality } \\
\text { (Q15) }\end{array}$ \\
\hline Social S-HH & ns & ns & ns & ns & ns \\
\hline $\begin{array}{l}\text { Social S- } \\
\text { Health/Life }\end{array}$ & ns & $p<0.001$ & ns & ns & ns \\
\hline $\begin{array}{l}\text { Social S- } \\
\text { Ing/Maths/Phys/ } \\
\text { Chem }\end{array}$ & ns & $p<0.05$ & $p<0.05$ & $p<0.05$ & ns \\
\hline $\mathrm{HH}-\mathrm{Health}$ & ns & $p<0.001$ & $p<0.05$ & ns & ns \\
\hline $\begin{array}{l}\mathrm{HH}- \\
\text { Ing/Maths/Phys/ } \\
\text { Chem }\end{array}$ & ns & $p<0.05$ & $p<0.001$ & $p<0.001$ & ns \\
\hline $\begin{array}{l}\text { Health- } \\
\text { Ing/Maths/Phys/ } \\
\text { Chem }\end{array}$ & ns & ns & ns & ns & ns \\
\hline
\end{tabular}

The factors that lead researchers to publish in a journal are, in order of importance, career advancement, the impact factor, the importance of the journal in their field, and speed of publication (Kocken \& Wical, 2013). Researchers choose the journals that are best suited to the system of scholarly communication and career advancement and that offer most advantages in each subject area. Researchers in medicine and life sciences are most influenced by the impact factor and will be more likely to publish in open access journals if they have a high factor. On the other hand, researchers in social sciences and humanities give more importance to citations and publish in journals that are important to their field. In other words, the reputation of the open access journal is essential for them (Eger et al., 2015).

\subsection{Open access at the University of Navarra}

This section of the survey asked whether respondents were aware of the University's open access initiatives and how they had found out about them. To avoid any possible doubt, the question about institutional policy included a link to the web page explaining the University's current open access policy. 
The majority of respondents were aware of the University's open access policy, but researchers in the 45-60+ age group showed the highest number of affirmative responses (78\%, Figure 4).This relationship between age and knowledge of the policy can be linked to a longer association with the university and possibly with greater participation in governing bodies, which means that the full information reaches them earlier and directly. Whether we studied the results by age or by type of user, we observed that professors and researchers found out about the policy primarily from the academic authorities, secondly from colleagues and finally from the library blog or website. Doctoral students also learn about the policy mainly from the academic authorities but secondly from the library blog and the university website. These results support the finding that age and category are strongly related to awareness of the open access policy because senior researchers are more likely to have closer relations with the academic authorities.

Figures 4. Responses about awareness of the institutional open access policy and repository by age.
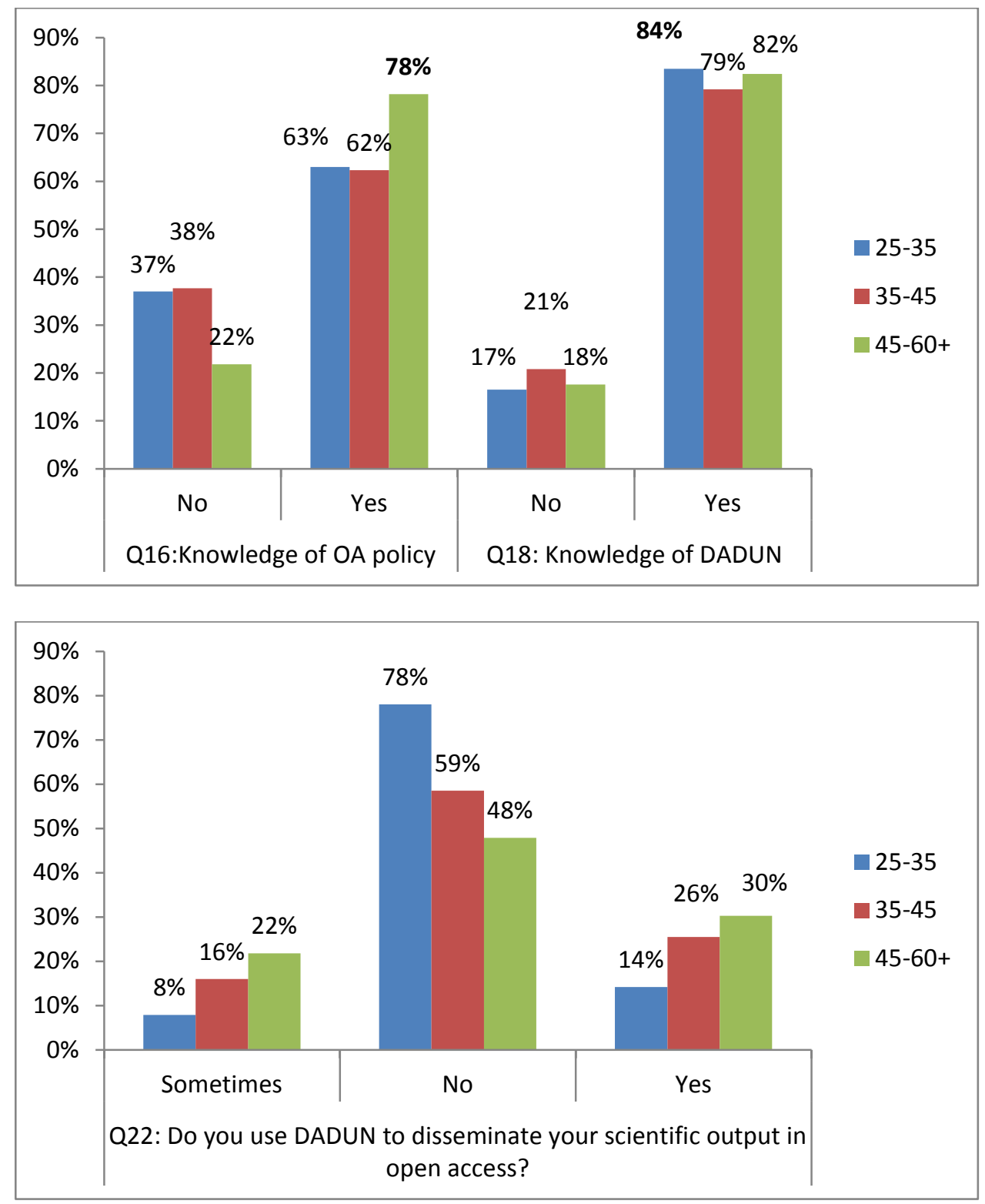


\subsubsection{Awareness and use of DADUN}

In 2014 two developments contributed greatly to the increase in documents in DADUN. First, the University's current research information system (Cientificacvn) was linked to DADUN, so researchers are now able to upload their research to DADUN with a single click. Second, the University announced a mandate for depositing doctoral theses, and also recommended depositing scholarly publications if it was allowed by the publishers. In addition, the University of Navarra signed the Berlin Declaration in June 2015.

The high percentage of users who are aware of DADUN (Q18-Q22) (over 70\%) contrasts with the low use that is made of it. The frequency of access to DADUN is minimal: of the respondents, $66.7 \%$ said that they never or rarely accessed it, compared with $33.3 \%$ who did. The respondents found out about DADUN mainly through the library (sessions, 28\%; website, 24\%; Open Access Week, 2\%); through institutional information such as the request to deposit documents by the academic authorities (15\%); through the weekly newsletter for employees of the University (4\%); or through the information displays in buildings (2\%). Some found out about DADUN through a colleague (10\%) or in other ways (1\%). Of the respondents, $12 \%$ stated that they did not know the repository.

Of the younger researchers, $78 \%$ did not use DADUN to disseminate their scientific outputs in open access. The majority of the older researchers claimed to know the open access policy, but few (14\%) used the repository to disseminate their scholarly outputs.

The analysis by subject area for Q16, Q18, Q20, Q21 and Q22 revealed a dependency between discipline and the responses: researchers in medicine and life sciences seemed less aware of the repository and most did not access it or use it to distribute their research (Figure 5)

Figures 5. Responses about awareness of the institutional open access policy and repository by subject.

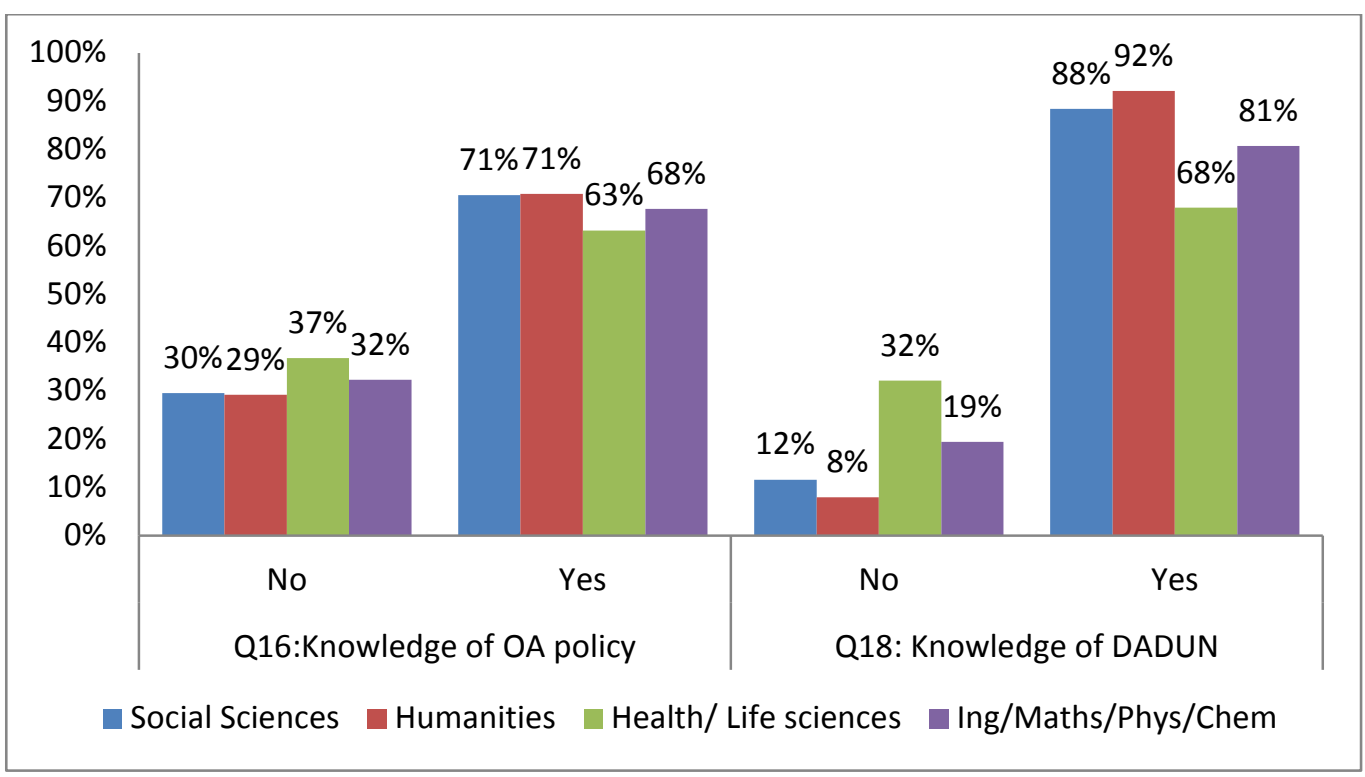




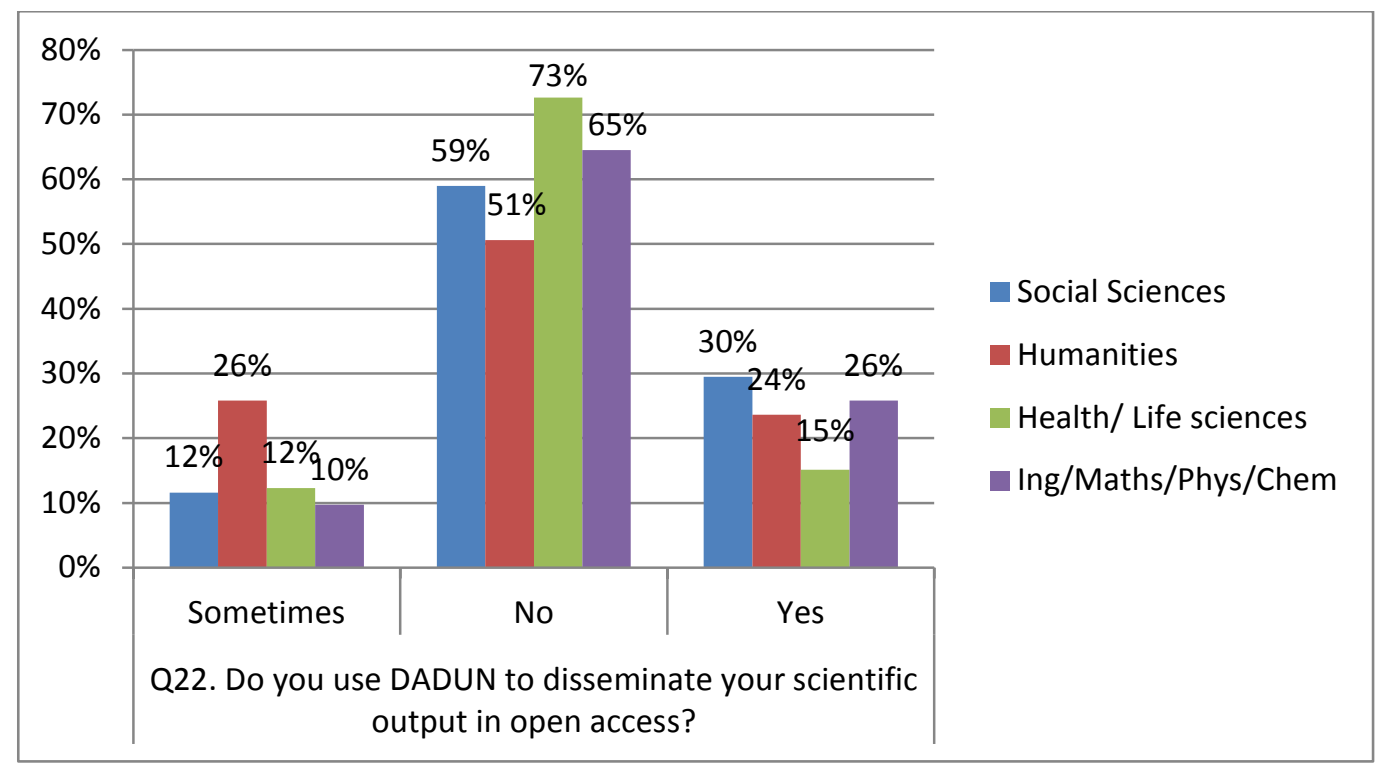

In the literature study we found controversial results: some authors stated that the use of subject repositories in the subject area does not lead to greater use of the institutional repository (Xia, 2007). However, others report that researchers in medicine and life sciences are more active in journals and more reluctant to deposit on online platforms, while researchers in mathematics, physics and economics are more likely to self-archive because there are subject repositories in their subjects (Eger et al., 2015). This was the case in our study, where researchers who were more familiar with using subject repositories (those in physics and mathematics) were the first and most consistent contributors to the repository.

Regarding access, use and reasons to deposit in DADUN, respondents stated to access DADUN mainly through the website of the Library, followed by the University website and Google. In response to the question of who deposited documents in the repository, the most frequent answer was the respondents themselves, followed by librarians and administrative staff. By areas, in medicine and life sciences the documents were mainly deposited by librarians; in social sciences self-archiving was predominant; and in both humanities and the physical sciences self-archiving and librarians were used to a similar extent (Figure 6).

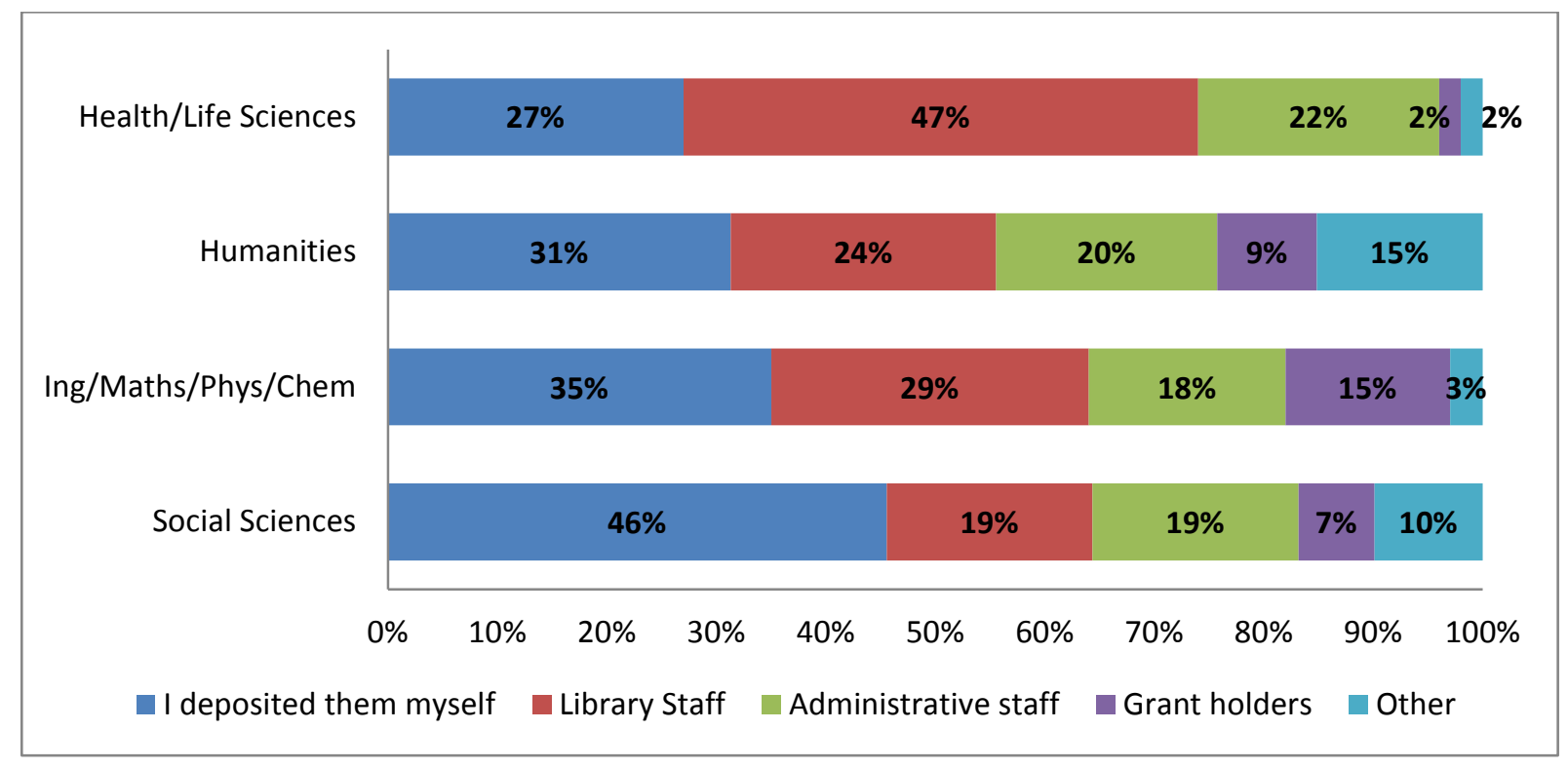

Figure 6.Who deposits by working area of respondents 
By age groups, the reason most mentioned by the 45-60+ age group in our survey was the responsibility of placing their work in open access, and some mentioned publicizing the university through their research. These users were more identified with the institution and wanted to promote it. Researchers in the middle age group archived their research in the repository mainly on the recommendation of the institution (academic reward). Finally, the reason most mentioned by younger researchers was to publicize their research outside the university ("publicity", see(Kim, 2007, 2011).

The most frequent reasons for depositing documents were: the recommendation by the academic authorities $(24 \%)$, the responsibility to place their work in open access $(23 \%)$, the desire to publicize their research outside the university $(23 \%)$ the desire to make their research known within the university (14\%), the offer by a repository manager offered to deposit their work in their name (6\%), encouragement by a colleague (4\%), the inability to access the journal from their institution (4\%), and the requirement of a funding agency (1\%). In the survey conducted by Taylor \& Francis, the most frequent reason was the personal responsibility to place their work in open access, followed by requests from colleagues, and thirdly the request of the institution (Frass et al., 2014). Therefore, the two coinciding reasons between the two studies are the mandate of the institution and what Kim called altruism in her model of the factors driving participation in institutional repositories (Kim, $2007,2011)$, i.e. the desire to share their publications with others.

The difficulties in depositing documents in the repository most mentioned were, in this order, lack of knowledge of editorial policies, lack of time, and lack of knowledge of how to upload documents to the repository. These were also the three most common reasons for not depositing documents in the survey of Taylor \& Francis (Frass et al., 2014). Lack of technical knowledge and copyright are also mentioned in other studies (Creaser et al., 2010; Kim, 2007; Lwoga \& Questier, 2015; Yang \& Li, 2015). Other difficulties are not knowing the embargo time of the documents, not wanting to deposit documents that have not been reviewed (Creaser et al., 2010) and the repository's reputation or lack of it (Eger et al., 2015).

Of the respondents, $51 \%$ answered that they had not obtained any advantage from depositing their documents in the repository. The advantage most mentioned was receiving citations from the documents deposited (19\%), followed by making contact with colleagues $(13 \%)$, and finally having received more messages on the documents deposited in the repository (7\%). These are the factors that Kim (Kim, 2007) considers extrinsic benefits.

In answer to the question on whether they linked to their documents in DADUN from other pages, the researchers answered that they did so most frequently from their personal website (31\%), second from the University's current research information system, Cientificacvn (20\%) and third from the Adi learning platform (18\%). Others linked from the department website (15\%) or from other pages, such as Academia.edu, ResearchGate, Linkedln and subject repositories (11\%).

\section{5. Services provided by the repository}

Respondents were asked to state how important some of the services provided by the institutional repository were for them (Figure 7). 
Figure 7. Contingency table of questions about services offered by repository managers

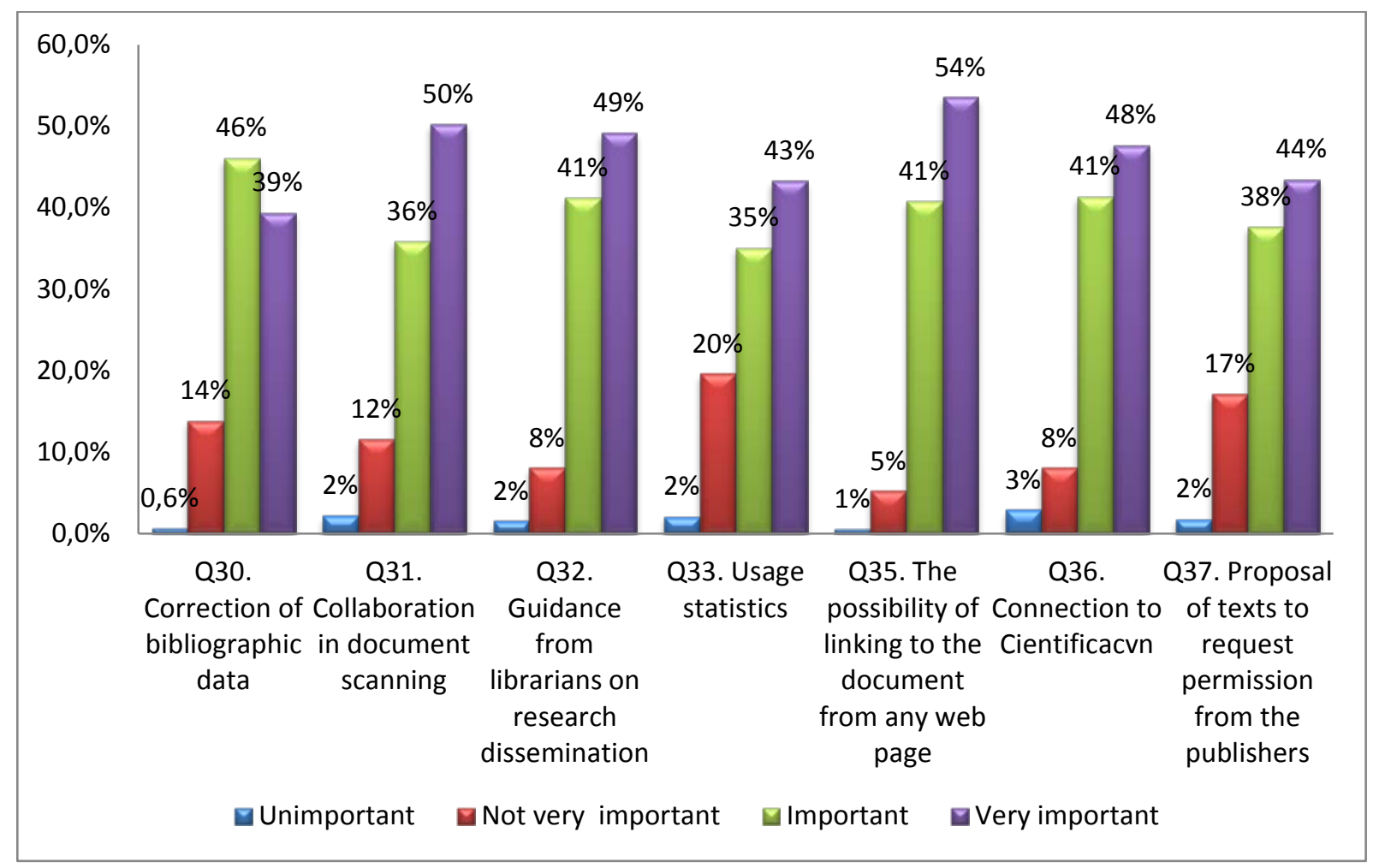

The analysis by age showed a great dependency between all the services. An average of $70 \%$ of respondents considered them "important" or "very important". The services provided were therefore highly valued, though the repository showed a low level of use. According to the KruskalWallis test, the only significant difference $(p<0.05)$ found for the correction of metadata was between the 25-35 and 35-45 age groups and the over the 45-60+ age group, who showed the lowest mean. This finding confirms the data obtained in the chi-squared analysis.

The services were highly valued by all age groups, although a significant difference was found in the correction of bibliographic data, which was slightly more important for young researchers. Nevertheless, $70 \%$ of the respondents considered this factor important or very important. Perhaps the most striking feature is that the most valued aspect was the ability to link from other websites rather than usage statistics, which could have been expected to be more useful for the dissemination of documents.

The dependence of the response on the subject area was significant only in the document scanning service. In social sciences and humanities differed significantly from medicine and life sciences and physical sciences with regard to document scanning.

Researchers in social sciences and humanities were those who most valued this service, probably because of the role played by the library in the digitization of document collections in these areas. The bivariate analysis between different subject areas (Table 3 ) again showed that social sciences and humanities differed from medicine and life sciences and physical sciences in their assessment of services. 
Table 3. Significance of Mann-Whitney $U$ test to compare pairwise subject categories to different services offered by repository managers (empty cells means $p>0.05$ ).

\begin{tabular}{|c|c|c|c|c|c|c|}
\hline & $\begin{array}{l}\text { Social- } \\
\text { Humanities }\end{array}$ & $\begin{array}{l}\text { Social- } \\
\text { Health/life }\end{array}$ & $\begin{array}{l}\text { Social- } \\
\text { Ing/Maths/Ph } \\
\text { y/Chem }\end{array}$ & $\begin{array}{l}\text { Humanities- } \\
\text { Health/Life }\end{array}$ & $\begin{array}{l}\text { Humanities- } \\
\text { Ing/Phy/Che } \\
\mathrm{m}\end{array}$ & $\begin{array}{l}\text { Health/Life - } \\
\text { Ing/Maths/P } \\
\text { hy/Chem }\end{array}$ \\
\hline $\begin{array}{l}\text { Frecuency_accessDadun } \\
\text { (Q20) }\end{array}$ & & $p<0.001$ & $p<0.001$ & $p<0.001$ & $p<0.001$ & \\
\hline Dissemination (Q22) & $p<0.05$ & ns & ns & ns & ns & ns \\
\hline $\begin{array}{c}\text { Correction_Metadata } \\
(\mathrm{Q} 30)\end{array}$ & ns & ns & ns & ns & ns & ns \\
\hline Digitalization (Q31) & & $p<0.05$ & $p<0.05$ & $p<0.05$ & $p<0.05$ & \\
\hline $\begin{array}{c}\text { Guidance_dissemination( } \\
\text { Q32) }\end{array}$ & ns & ns & $p<0.05$ & ns & ns & ns \\
\hline Use_statistics (Q33) & ns & ns & ns & ns & ns & ns \\
\hline $\begin{array}{c}\text { Conection_SocialNetworks } \\
\text { (Q34) }\end{array}$ & ns & ns & ns & ns & ns & ns \\
\hline $\begin{array}{c}\text { Conection_Other_Webs } \\
\text { (Q35) }\end{array}$ & $p<0.05$ & & $p<0.05$ & ns & ns & ns \\
\hline Conection_CRIS (Q36) & ns & ns & ns & ns & ns & ns \\
\hline $\begin{array}{c}\text { Request_Permissions } \\
\text { (Q37) }\end{array}$ & ns & ns & $p<0.05$ & ns & ns & ns \\
\hline
\end{tabular}

In this study the two most valued services were related to the dissemination of research: the possibility of linking to documents from other websites and guidance from the library. The role of the library in providing guidance on the dissemination of research, which has partly arisen thanks to the development of the institutional repository, is thus seen by researchers as yet another library service.

\section{Conclusions}

The good opinion of open access among researchers at the University of Navarra does not correspond to their use of the institutional repository. The respondents considered that placing their work in open access also includes linking it from personal or departmental web pages, and especially from academic platforms (Academia.edu or ResearchGate). They stated that on these platforms it is much easier to introduce the documents and that they ensure the attention of their colleagues.

The decision to publish in open access journals or to deposit in repositories is closely related to academic reward and professional recognition. The various models of scholarly communication according to subject areas greatly influence this. In science, technology and medicine, publishing in journals furthers academic careers, and many of the journals are open access. Researchers in these areas are therefore more likely to publish in open access journals. In humanities and social sciences there are not many high-quality open access journals. Researchers in these areas either deposit their research in the repository for institutional reasons (the mandate or a desire to help the institution) or to attain more visibility and citations.

The services offered by the repository of the University of Navarra were positively perceived in general, with some differences depending on the respondent's age and subject area. The greatest 
differences were perceived in the correction of bibliographic data (the younger the researchers, the more they valued this service) and document scanning (most valued by researchers of social sciences and humanities, who have less scientific literature digitized). The study of the evaluation of these services reveals that the library has become an aid to the dissemination of research.

This type of study on repository users' habits and needs is especially useful for academic libraries, who can use the results to improve the way repositories work and make them support users' research activities more effectively.

The results of this survey suggest that, given a tool for disseminating its services more widely, the institutional repository could become more important to the academic community. The survey reveals that although researchers are aware of the repository, they are unsure how to use it to disseminate their own research. At the University of Navarra, the library's recently-created Bibliometric Service (Iribarren-Maestro, Grandal, Alecha, Nieva, \& San-Julián, 2015) could help raise academic awareness about the depository, as could the subject-specific training librarians offer. Furthermore, the mediated deposit service, which is actually already available, and the improvement of the repository's system interoperability (especially with CRIS) could help remedy researchers' lack of time and technical know-how. Now that users find it easy to upload research to academic platforms, they are being advised to deposit not their full texts but only the URLs, which can be used to centralize the statistics on use and downloads and also guarantee compliance with publication policy, given that the library can revise the repository registers.

In this way, the library takes on an essential role in supporting research, not only through its institutional repository service per se, but through its guidance to users wishing to disseminate their research and its promotion of academic activity.

\section{Acknowledgements}

This study was carried out under the project "Open Access to Science in Spain" (CSO2014-52830-P) of the Spanish R\&D Plan funded by the Spanish Ministry of Science and Innovation.

\section{Bibliography}

Bongiovani, P. C., Guarnieri, G., Babini, D., \& Lopez, F. A. (2014). Acceso abierto en la Universidad Nacional de Rosario necesidades y practicas de los docentes/investigadores. Informacion, Cultura Y Sociedad, (30), 13. Retrieved from http://ezproxy.si.unav.es:2048/login?url=http://search.ebscohost.com/login.aspx?direct=true\& AuthType=ip,url\&db=edsgao\&AN=edsgcl.377662961\&lang=es\&site=eds-live

Commission, E., \& Directorate-General for Research, and I. (2012). Online survey on scientific information in the digital age. http://doi.org/10.2777/7549

Creaser, C., Fry, J., Greenwood, H., Oppenheim, C., Probets, S., Spezi, V., \& White, S. (2010). Authors' Awareness and Attitudes Toward Open Access Repositories. New Review of Academic Librarianship, 16(sup1), 145-161. http://doi.org/10.1080/13614533.2010.518851

Eger, T., Scheufen, M., Meierrieks, D., Eger, T., Scheufen, M., \& Meierrieks, D. (2015). The determinants of open access publishing: survey evidence from Germany. European Journal of Law and Economics, 39, 475-503. http://doi.org/10.1007/s10657-015-9488-x 
Frass, W., Cross, J., \& Gardner, V. (2014). Open access survey-June 2014. Taylor \& Francis; Routledge. Retrieved from http://www.tandf.co.uk/journals/explore/open-access-survey-june2014.pdf

Iribarren-Maestro, I., Grandal, T., Alecha, M., Nieva, A., \& San-Julián, T. (2015). Apoyando la investigación: nuevos roles en el Servicio de Bibliotecas de la Universidad de Navarra. Supporting Research: New Roles in the Library Services of University of Navarra., 24(2), 131137. Retrieved from 10.3145/epi.2015.mar.06

Kim, J. (2007). Motivating and Impeding Factors Affecting Faculty Contribution to Institutional Repositories. Journal of Digital Information, 8(2). Retrieved from https://journals.tel.org/jodi/index.php/jodi/article/view/193/177

Kim, J. (2011). Motivations of Faculty Self-archiving in Institutional Repositories. The Journal of Academic Librarianship, 37(3), 246-254. http://doi.org/10.1016/j.acalib.2011.02.017

Kocken, G. J., \& Wical, S. H. (2013). "I've Never Heard of It Before " : Awareness of Open Access at a Small Liberal Arts University. Behavioral \& Social Sciences Librarian, 32, 140-154. http://doi.org/10.1080/01639269.2013.817876

Lwoga, E. T., \& Questier, F. (2015). Open access behaviours and perceptions of health sciences faculty and roles of information professionals. Health Information \& Libraries Journal, (1), 37. http://doi.org/10.1111/hir.12094

Lynch, C. A. (2003). Institutional Repositories: Essential Infrastructure For Scholarship In The Digital Age. Portal: Libraries and the Academy VO - 3, (2), 327. Retrieved from http://ezproxy.si.unav.es:2048/login?url=http://search.ebscohost.com/login.aspx?direct=true\& AuthType=ip,url\&db=edspmu\&AN=edspmu.S1530713103203275\&lang=es\&site=edslive\&scope=site

Niyazov, Y., Vogel, C., Price, R., Lund, B., Judd, D., Akil, A., ... Shron, M. (2016). Open Access Meets Discoverability: Citations to Articles Posted to Academia.edu. PLOS ONE VO - 11, (2). http://doi.org/10.1371/journal.pone.0148257

Oguz, F., \& Assefa, S. (2014). Library Review Faculty members' perceptions towards institutional repository at a medium-sized university: Application of a binary logistic regression model. Library Review Library Review Library Hi Tech, 63(3), 189-202. Retrieved from http://dx.doi.org/10.1108/LR-07-2013-0088

Pérez, F. (dir). (2015). Rankings ISSUE 2015: Indicadores sintéticos de las universidades españolas. Retrieved from http://www.u-ranking.es/descargas/Informe-rankings-universidades-FBBVAIvie-2015.pdf

Serrano-Vicente, R., Melero, R., \& Abadal, E. (2014). Indicadores para la evaluación de repositorios institucionales de acceso abierto. Anales de Documentacion, 17(2).

http://doi.org/10.6018/analesdoc.17.2.190821

Spezi, V., Fry, J., Creaser, C., Probets, S., White, S., Fry, J., \& Probets, S. (2013). Researchers' green open access practice: A cross-disciplinary analysis. Journal of Documentation, 69(3), 334-359. http://doi.org/10.1108/JD-01-2012-0008

Xia, J. (2007). Assessment of Self-archiving in Institutional Repositories: Across Disciplines. Journal of Academic Librarianship. http://doi.org/10.1016/j.acalib.2007.09.020

Yang, Z. Y., \& Li, Y. (2015). University Faculty Awareness and Attitudes towards Open Access Publishing and the Institutional Repository: A Case Study. Journal of Librarianship and Scholarly 
Communication, 3(31). http://doi.org/10.7710/2162-3309.1210 
Figure 1. Responses about open access by subject of respondents.

Figure 2. Publication in open access by working area of respondents

Figure 3. Opinion about Open Access Journals (Total)

Figures 4. Responses about awareness of the institutional open access policy and repository by age.

Figures 5. Responses about awareness of the institutional open access policy and repository by subject.

Figure 6.Who deposits by working area of respondents

Figure 7. Responses about services offered by repository managers by age of respondents

Figure 8. Responses about services offered by repository managers by subject 
Figure 1. Responses about open access by working area of respondents.

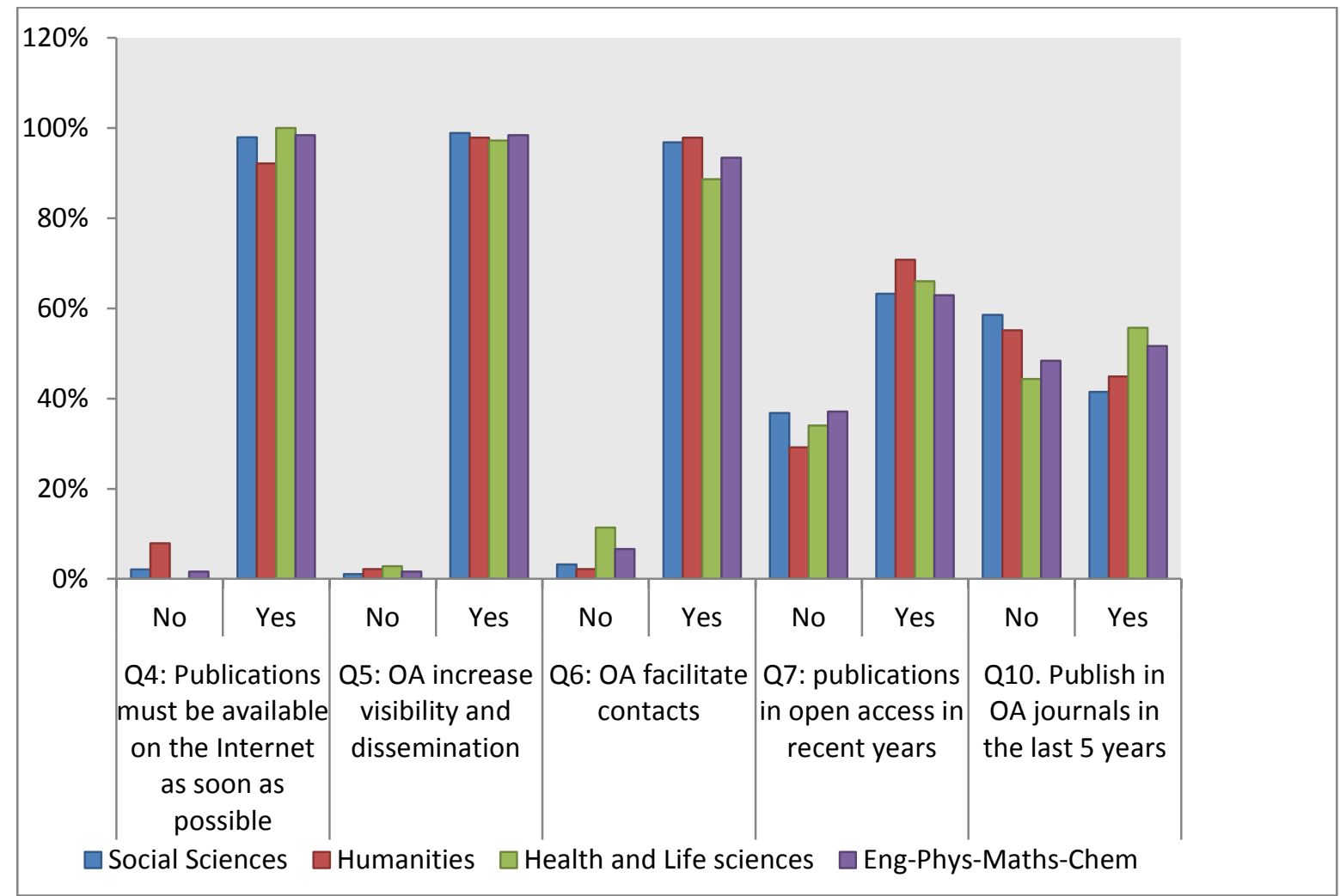




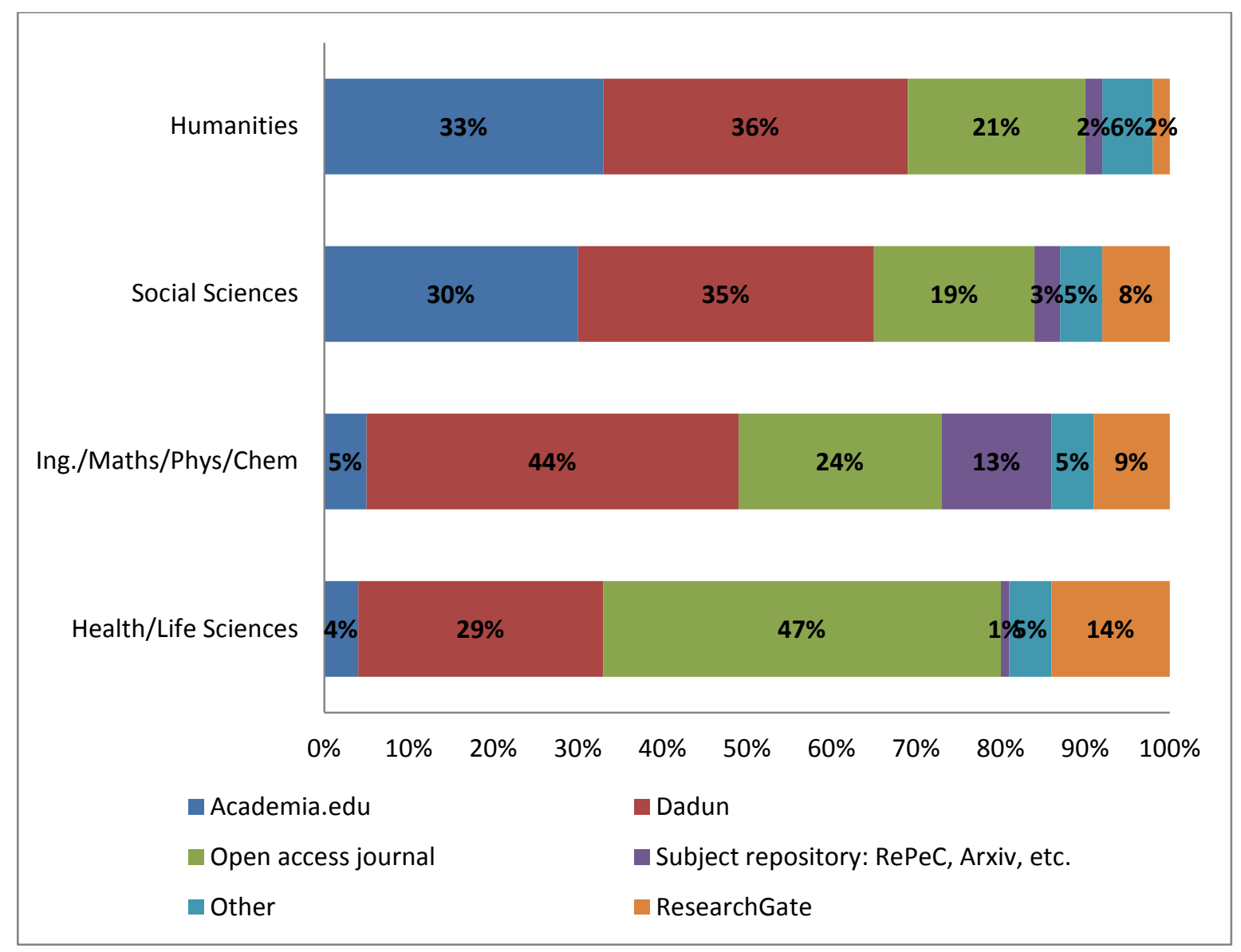

Figure 2. Publication in open access by working area of respondents 


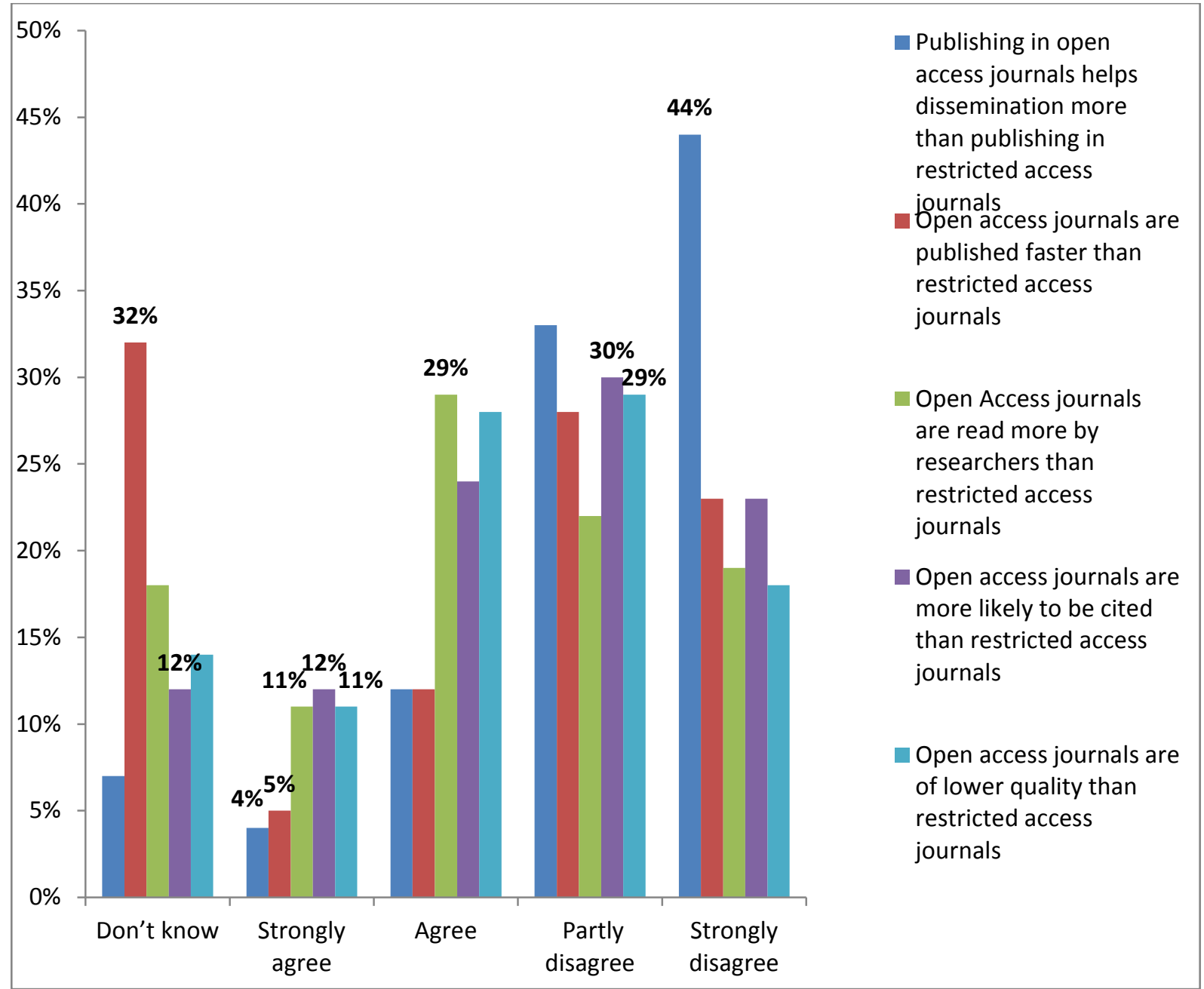

Figure 3. Opinion about Open Access Journals (Total) 
Figures 4. Responses about awareness of the institutional open access policy and repository by age.
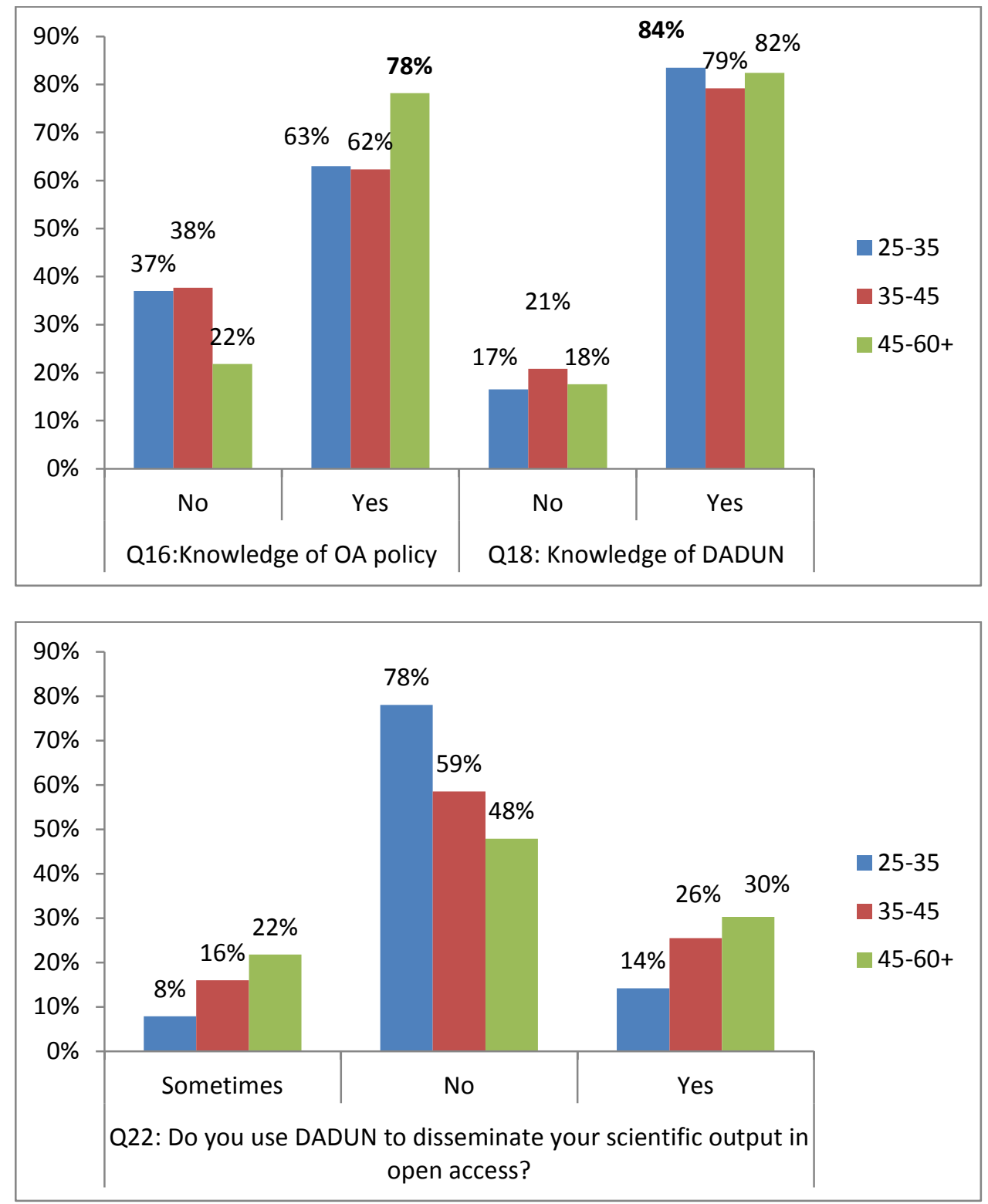
Figures 5. Responses about awareness of the institutional open access policy and repository by subject.
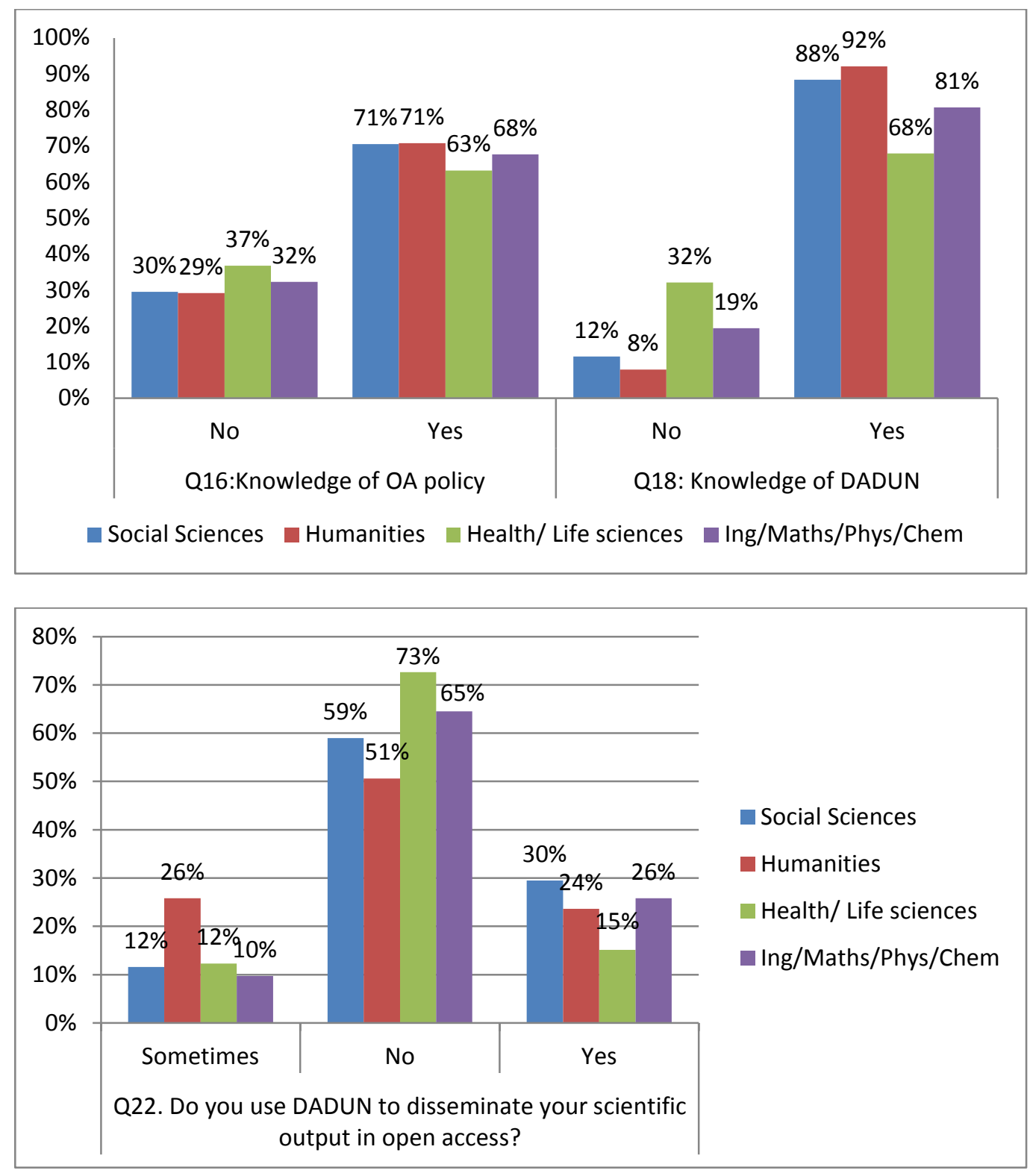


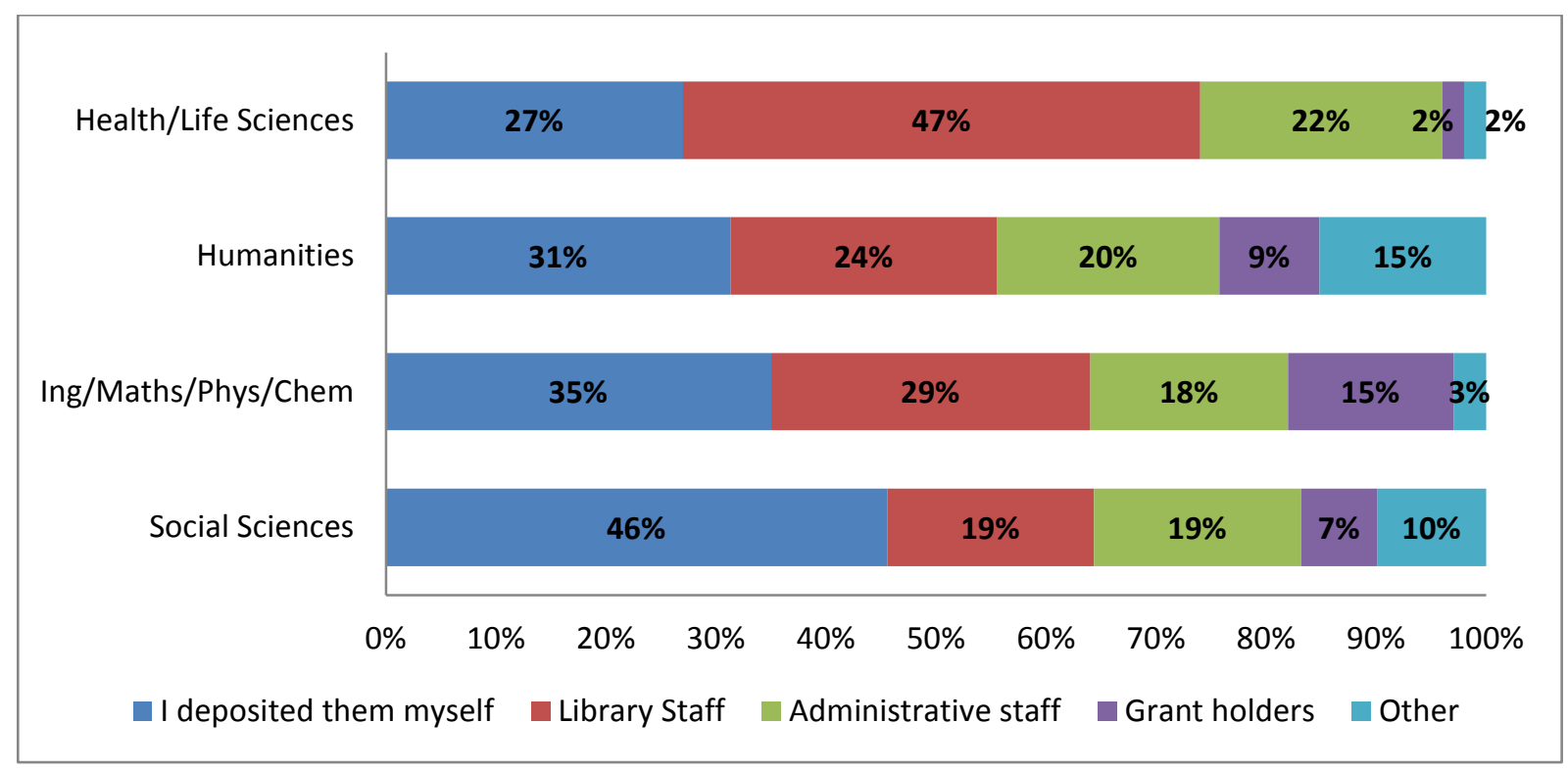

Figure 6. Who deposits by working area of respondents 
Figure 7. Contingency table of questions about services offered by repository managers

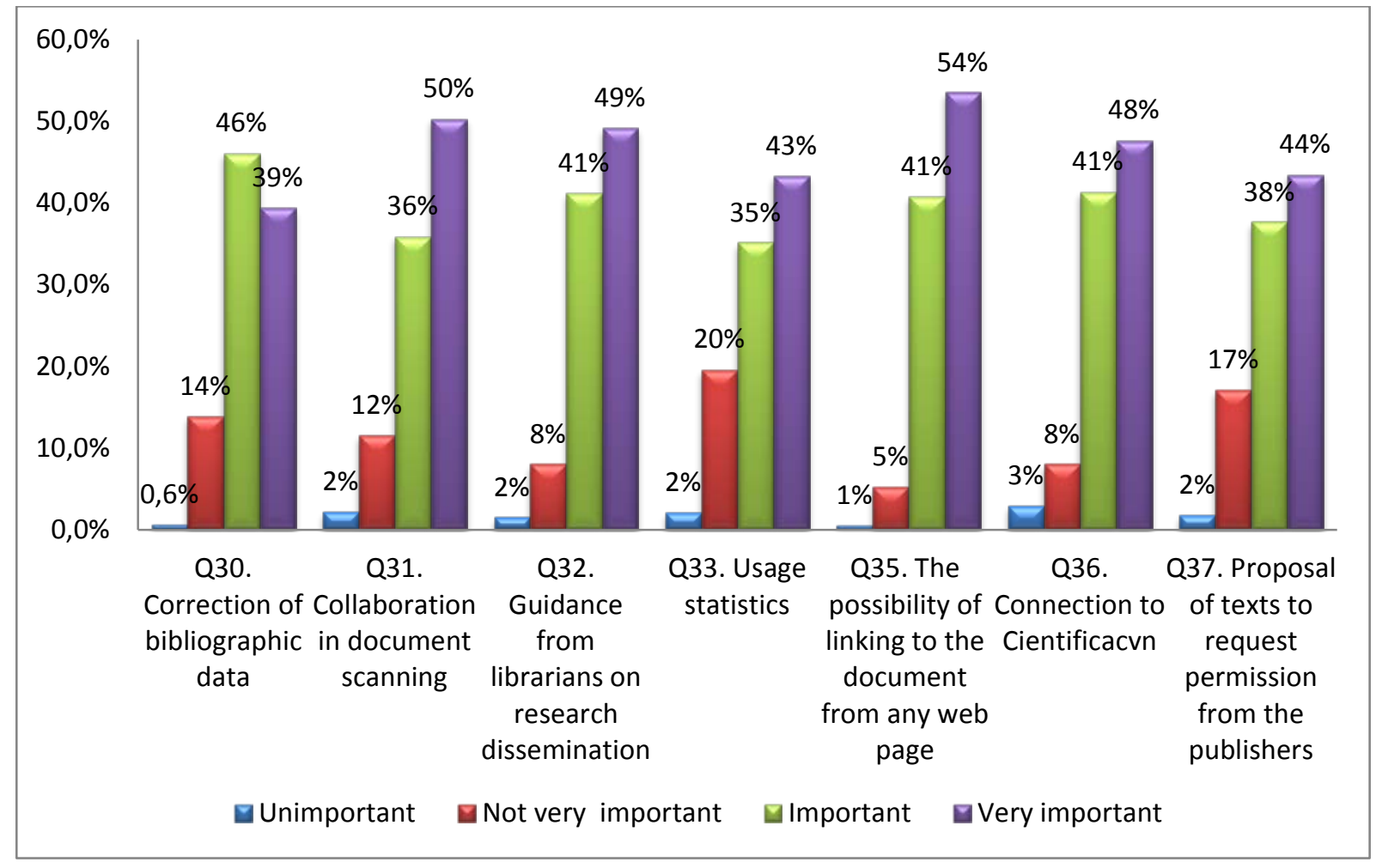


Table1. Groups of respondents by age and working area.

\begin{tabular}{|l|r|r|r|}
\hline \multirow{2}{*}{ Working area } & \multicolumn{3}{|c|}{ Age } \\
\cline { 2 - 4 } & $\mathbf{2 5 - 3 5}$ & $\mathbf{3 5 - 4 5}$ & $\mathbf{4 5 - 6 0 +}$ \\
\hline Social sciences & $31.6 \%$ & $29.5 \%$ & $38.9 \%$ \\
\hline Humanities & $34.8 \%$ & $33.7 \%$ & $31.5 \%$ \\
\hline Health and Life sciences & $38.7 \%$ & $27.4 \%$ & $34.0 \%$ \\
\hline $\begin{array}{l}\text { Engineering, Physics, } \\
\text { Maths and Chemistry }\end{array}$ & $40.3 \%$ & $30.6 \%$ & $29.0 \%$ \\
\hline
\end{tabular}

Table 2. Mann-Whitney $U$ test to compare questions about open access journals by pairs of subject categories (empty cells means $p>0.05$ )..

\begin{tabular}{|c|c|c|c|c|c|}
\hline & $\begin{array}{c}\text { OA } \\
\text { journals } \\
\text { +Dissemin } \\
\text { ation } \\
\text { (Q11) } \\
\end{array}$ & $\begin{array}{c}\text { OA } \\
\text { journals_+Rapid } \\
(\mathrm{Q} 12)\end{array}$ & $\begin{array}{c}\mathrm{OA} \\
\text { journals_+Read } \\
(\mathrm{Q} \overline{13})\end{array}$ & $\begin{array}{c}\mathrm{OA} \\
\text { journals_+Cited } \\
(\mathrm{Q} 14)\end{array}$ & $\begin{array}{c}\text { OA } \\
\text { journals_+Quality } \\
(\mathrm{Q} 15)\end{array}$ \\
\hline Social S-HH & ns & ns & ns & ns & ns \\
\hline $\begin{array}{l}\text { Social S- } \\
\text { Health/Life }\end{array}$ & ns & $p<0.001$ & ns & ns & ns \\
\hline $\begin{array}{l}\text { Social S- } \\
\text { Ing/Maths/Phys/ } \\
\text { Chem }\end{array}$ & ns & $p<0.05$ & $p<0.05$ & $p<0.05$ & ns \\
\hline $\mathrm{HH}-\mathrm{Health}$ & ns & $p<0.001$ & $p<0.05$ & ns & ns \\
\hline $\begin{array}{l}\mathrm{HH}- \\
\text { Ing/Maths/Phys/ } \\
\text { Chem }\end{array}$ & ns & $p<0.05$ & $p<0.001$ & $p<0.001$ & ns \\
\hline $\begin{array}{l}\text { Health- } \\
\text { Ing/Maths/Phys/ } \\
\text { Chem }\end{array}$ & ns & ns & ns & ns & $\mathrm{ns}$ \\
\hline
\end{tabular}


Table 3. Significance of Mann-Whitney $U$ test to compare pairwise subject categories to different services offered by repository managers (empty cells means $p>0.05$ ).

\begin{tabular}{|c|c|c|c|c|c|c|}
\hline & $\begin{array}{l}\text { Social- } \\
\text { Humanities }\end{array}$ & $\begin{array}{l}\text { Social- } \\
\text { Health/life }\end{array}$ & $\begin{array}{l}\text { Social- } \\
\text { Ing/Maths/Ph } \\
\text { y/Chem }\end{array}$ & $\begin{array}{l}\text { Humanities- } \\
\text { Health/Life }\end{array}$ & $\begin{array}{l}\text { Humanities- } \\
\text { Ing/Phy/Che } \\
\mathrm{m}\end{array}$ & $\begin{array}{l}\text { Health/Life - } \\
\text { Ing/Maths/P } \\
\text { hy/Chem }\end{array}$ \\
\hline $\begin{array}{l}\text { Frecuency_accessDadun } \\
\text { (Q20) }\end{array}$ & & $p<0.001$ & $p<0.001$ & $p<0.001$ & $p<0.001$ & \\
\hline Dissemination (Q22) & $p<0.05$ & ns & ns & ns & ns & ns \\
\hline $\begin{array}{c}\text { Correction_Metadata } \\
(\mathrm{Q} 30)\end{array}$ & ns & ns & ns & ns & ns & ns \\
\hline Digitalization (Q31) & & $p<0.05$ & $p<0.05$ & $p<0.05$ & $p<0.05$ & \\
\hline $\begin{array}{c}\text { Guidance_dissemination( } \\
\text { Q32) }\end{array}$ & ns & ns & $p<0.05$ & ns & ns & ns \\
\hline Use_statistics (Q33) & ns & ns & ns & ns & ns & ns \\
\hline $\begin{array}{c}\text { Conection_SocialNetworks } \\
\text { (Q34) }\end{array}$ & ns & ns & ns & ns & ns & ns \\
\hline $\begin{array}{c}\text { Conection_Other_Webs } \\
\text { (Q35) }\end{array}$ & $p<0.05$ & & $p<0.05$ & ns & ns & ns \\
\hline Conection_CRIS (Q36) & ns & ns & ns & ns & ns & ns \\
\hline $\begin{array}{c}\text { Request_Permissions } \\
\text { (Q37) }\end{array}$ & ns & ns & $p<0.05$ & ns & ns & ns \\
\hline
\end{tabular}

